\title{
Role of Nanoclays in Carbon stabilization in Andisols and Cambisols
}

\author{
M. Calabi-Floody ${ }^{1 *}$, C. Rumpel ${ }^{2}$, G, Velásquez ${ }^{1}$, A. Violante ${ }^{3}$, R. Bol ${ }^{4}$, L.M. Condron$^{5}$, \\ M.L. Mora ${ }^{1}$ \\ ${ }^{a}$ Center of Plant, Soil Interaction and Natural Resources Biotechnology, Scientific and Biotechnological \\ Bioresource Nucleus (BIOREN-UFRO), Avenida Francisco Salazar 01145, Universidad de La Frontera, \\ Temuco, Chile. ${ }^{b}$ CNRS, IEES, Campus AgroParisTech, Thiverval-Grignon, France. ${ }^{c}$ Dipartimento di Agraria, \\ Università Degli Studi di Napoli Federico II, Naples, Italy. 'Institute of Bio-and Geosciences, IBG-3: Agrosphere, \\ Forschungszentrum Jülich, 52428, Jülich, Germany. ${ }^{e}$ Faculty of Agriculture and Life Sciences, PO Box 85084, \\ Lincoln University, Christchurch 7647, New Zealand.*Corresponding author:marcela.calabi@ufrontera.cl
}

\begin{abstract}
Greenhouse gas (GHG) emissions and their consequent effect on global warming are an issue of global environmental concern. Increased carbon (C) stabilization and sequestration in soil organic matter (SOM) is one of the ways to mitigate these emissions. Here we evaluated the role of nanoclays isolated from soil on $\mathrm{C}$ stabilization in both a $\mathrm{C}$ rich Andisols and $\mathrm{C}$ depleted Cambisols. Nanoclays were analyzed for size and morphology by transmission electron microscopy, for elemental composition and molecular composition using pyrolysis-GC/MS. Moreover, nanoclays were treated with $\mathrm{H}_{2} \mathrm{O}_{2}$ to isolate stable SOM associated with them. Our result showed better nanoclay extraction efficiency and higher nanoclay yield for Cambisol compared to Andisols, probably related to their low organic matter content. Nanoclay fractions from both soils were different in size, morphology, surface reactivity and SOM content. Nanoclays in Andisols sequester around 5-times more $\mathrm{C}$ than Cambisols, and stabilized 6 to 8-times more $\mathrm{C}$ than Cambisols nanoclay after SOM chemical oxidation. Isoelectric points and surface charge of nanoclays extracted from the two soils was very different. However, the chemical reactivity of the nanoclay SOM was similar, illustrating their importance for $\mathrm{C}$ sequestration. Generally, the precise $\mathrm{C}$ stabilization mechanisms of both soils may be different, with nanoscale aggregation being more important in Andisols. We can conclude that independent of the soil type and mineralogy the nanoclay fraction may play an important role in $\mathrm{C}$ sequestration and stabilization in soil-plant systems.
\end{abstract}

Keywords: Nanoclays, Nanoparticles, Soil organic matter, Carbon stabilization, Pyrolysis, Andisols, Cambisols 


\section{Introduction}

Increased atmospheric carbon dioxide $\left(\mathrm{CO}_{2}\right)$ is the principal cause of the ongoing global warming (Lal, 2010). The majority of carbon (C) in terrestrial ecosystems is known to be present in the soil organic matter (SOM) (Batjes, 1996), and this pool can act as a source or a sink for atmospheric $\mathrm{CO}_{2}(\mathrm{Lal}, 2010)$ and thereby mitigating or enhancing the overall rise in atmospheric $\mathrm{CO}_{2}$ concentration and associated climate warming issues.

Natural nanoparticles $(<100 \mathrm{~nm})$ occur widely in the environment, especially in soils (Calabi-Floody et al., 2009, 2011; Montreal et al., 2010; Pan and Xing, 2012). It has been suggested that nanoclays could be effective in increasing soil water, carbon (C) and nutrient storage capacities, due to their large surface area (Khedr et al., 2006; Hiemstra et al., 2010; Hernández and Almendros, 2012; Regelink et al., 2013). The use of nanomaterials with their unique electronic, kinetic, magnetic and optical properties may enhance $\mathrm{C}$ stabilization in soil (Monreal et al., 2010; Calabi-Floody et al., 2011).

Nanomaterials in soils comprise clay minerals as well as metal oxides. A soil type naturally rich in nanomaterials is Andisol. These soils derived from volcanic ash naturally contain nanoclay, among which allophane is the most abundant (Parfitt et al., 1983; Wada, 1987; Calabi-Floody et al., 2009). Allophane is a non-crystalline aluminosilicate, and occurs as nano-spheres with an outer diameter of $3.5-5.0 \mathrm{~nm}$, with defects in the wall structure that give rise to perforations of $\sim 0.3 \mathrm{~nm}$ in diameter. It has been demonstrated that the extracted aggregates of Andisol nanoparticles retain a significant amount of $\mathrm{C}(11.8 \%)$ against intensive peroxide treatment (Calabi-Floody et al., 2011). This was attributed to physical and chemical protection due to the spatial et al., 2010; Chevallier et al. 2010; Calabi-Floody et al., 2011) and may therefore contribute to long-term storage of $\mathrm{C}$ in soil. However, Andisols represent only around $0.8 \%$ (around 110 to 124 million hectares at worldwide) of global soil area (FAO, 2001), but contain $6-8 \%$ of total soil C (Batjes, 1996).

The most common global soil type (based on land area) is Cambisol, it is also one of the major soil types widely used in food production, covering 1.5 billion hectares (FAO, 2001). Due to intensive agricultural use these soils are now generally $\mathrm{C}$ depleted and contain only 3\% of soil C (Batjes, 1996). Nanomaterials in this soil type may strongly differ from those of Andisols and comprise different clay minerals as well as iron and/or aluminum oxides.

The main objective of this work was to evaluate the role of the nanoclay fractions on $\mathrm{C}$ stabilization from a $\mathrm{C}$ rich Andisols and $\mathrm{C}$ depleted Cambisols. In particular we investigated extraction yields, amounts, turnover, and the composition of $\mathrm{C}$ associated with the nanoclay fractions of both soils.

\section{Materials and Methods}

\subsection{Soil preparation and clay extraction}

The soil samples were collected from a Chilean Andisols (UFRO experimental site) and French Cambisols (INRA experimental site, les Closeaux) all under agricultural management. The Andisols studied were Pemehue (PEH) $\left(39^{\circ} 04^{\prime} \mathrm{S}\right.$ and $\left.072^{\circ} 10^{\prime} \mathrm{W}\right)$ and Piedras Negras (PN) $\left(40^{\circ} 23^{\prime} \mathrm{S}\right.$ and $\left.072^{\circ} 30^{\prime} \mathrm{W}\right)$ series in Southern Chile (Soil Survey Laboratory Staff, 1996), both Andisols 0-20 cm depth were collected in 2011. The agricultural management in PEH series corresponds to annual crop (wheat) under traditional tillage, while PN is managed under permanent grassland (white clover + ryegrass). 
We also sampled an Eutric cambisol (Eu Cam) with a silt loam texture, located in the "Parc du Château de Versailles" (Centre INRA Versailles-Grignon, France). This experimental area had been thoroughly described in Dignac et al. (2005) and Bahri et al. (2006). Sampled Cambisols were both under agricultural annual cropping management; maize $(\mathrm{CM})$ and wheat $(\mathrm{CW})$. All soil samples were airdried (2-3 days at room temperature) and sieved at 2 $\mathrm{mm}$ discarding coarse plant residues.

Approximately, $100 \mathrm{~g}$ of each soil samples were used for clay extraction. Briefly, deionized water $(180 \mathrm{ml})$ was added to $50 \mathrm{~g}$ of air-dried bulk soil, and shaken overnight with 20 glass beads (diameter $5 \mathrm{~mm}$ ). The fraction $<50 \mu \mathrm{m}$ was collected after wet sieving. It was ultrasonicated applying 7,500 $\mathrm{J} \mathrm{g}^{-1}$, using a Sonics Vibra Cell model VC 550 equipment, the soil mass $(\mathrm{g})$ : water $(\mathrm{mL})$ ratio was 1:10. Around $14 \mathrm{~g}$ of soil suspension was placed in a one-liter measuring cylinder, from which the clay fraction $(<$ $2 \mu \mathrm{m}$ equivalent spherical diameter), was obtained by sedimentation under gravity, following Stokes' law. The separated clay suspension was concentrated by sedimentation overnight changing the ionic force achieved $1.8 \mathrm{M}$ with $\mathrm{NaCl}$.

For Cambisol fractionations three soil suspension cycles and sample sonications were used before clay isolation. With these standard procedures we were able to recover $100 \%$ of theoretical amount (Dignac et al., 2005). We increased de number of cycles to 15 for Andisols and we were then able to recover around $84 \%$ of theoretical content (Mella and Kühne, 1985). The clay extractions were performed in triplicate.

\subsection{Nanoclay extraction}

The nanoclay fraction was extracted using the methodology as described by Calabi-Floody et al. (2011). Briefly, $5 \mathrm{~g}$ of the clay was suspended in 100
$\mathrm{mL}$ of $1 \mathrm{M} \mathrm{NaCl}$, ultrasonicated at $5,600 \mathrm{~J} \mathrm{~g}^{-1}$, and centrifuged at $1350 \mathrm{~g}$ for $40 \mathrm{~min}$ and $25^{\circ} \mathrm{C}$. The firstround supernatant was discarded in order to remove vegetal and mineral impurities. The pellet was suspended in $50 \mathrm{~mL}$ of deionized water applying 750 $\mathrm{J} \mathrm{g}^{-1}$. The supernatant was collected, while the pellet was resuspended (in deionized water) by sonication and centrifuged, this stage was repeated 11 times for Andisols and 5 for Cambisols. The collected supernatants, containing the nanoclay, were dialyzed (1000 kDa membrane) against deionized water until the conductivity of the water reached $0.5-0.8 \mu \mathrm{S} \mathrm{cm}^{-1}$. The dialyzed material was freeze-dried to yield solid nanoclays. The nanoclay extractions were performed in triplicate.

\subsection{Transmission electron microscopy (TEM)}

A drop of the clay or nanoclay suspension $(1 \mu \mathrm{g}$ $\mathrm{mL}^{-1}$ ) was evaporated on a carbon-coated copper grid. TEM images were obtained with a Jeol-1200 EXII instrument operating at $120 \mathrm{kV}$, equipped with a Gatan 782 camera for image digitization. Electron diffraction (ED) was made at $60 \mathrm{~cm}$ from the focus.

\subsection{Elemental analyses and turnover}

Carbon and nitrogen contents were determined by dry combustion using a $\mathrm{CN}$ Elemental analyzer (CHN NA 1500, Carlo Erba). Stable C isotope ratios $\left(\delta^{13} \mathrm{C}\right)$ were determined with a $\mathrm{CHN}$ analyser coupled with a SIRA10 isotopic ratio mass spectrometer (Micromass). The results for isotope abundance are reported in per mil (\%) relative to the Pee Dee Belemnite standard. Accuracy of the elemental analysis was $\pm 0.1 \mathrm{mg} \mathrm{g}^{-1}$ for $\mathrm{C}$ and $\pm 0.05 \mathrm{mg} \mathrm{g}^{-1}$ for $\mathrm{N}$ content. The accuracy of isotope $\delta^{13} \mathrm{C}$ measurements was $\pm 0.3 \%$. Calculation of mean residence times of $\mathrm{C}$ was carried out using the carbon isotope signatures 
of the Cambisol under permanent wheat and after 9 years of maize cultivation. The proportion (F) of incorporated maize $\mathrm{C}$ in bulk and nanoclay fraction was calculated using the isotopic mass balance:

$$
\mathrm{F}=\left(\delta^{13} \mathrm{C} \text { soil wheat control }-\delta^{13} \mathrm{C} \text { soil } 9 \text { yrs maize }\right) /\left(\delta^{13} \mathrm{C}_{\text {wheat }}-\delta^{13} \mathrm{C}_{\text {maize }}\right)
$$

where $\delta^{13} \mathrm{Csoil}$ wheat control is the stable $\mathrm{C}$ isotope ratio of soil sampled under continuous wheat and $\delta^{13} \mathrm{C}$ soil ${ }_{9 \text { yrs }}$ maize is the stable $\mathrm{C}$ isotope ratio of soil sampled after 9 years of maize cultivation, $\delta^{13} \mathrm{C}_{\text {wheat }}-\delta^{13} \mathrm{C}_{\text {maize }}$ are the stable carbon isotope ratios of the wheat and maize plants respectively, these values were took from Dignac et al. (2005) who facilitated the Cambisol samples. From these data we then calculated the $\mathrm{C}$ incorporation per year and the mean residence time (MRT) as 1/incorporation rate.

\subsection{Chemical reactivity and electrophoretic mobility}

A portion of the nanoclay fractions was treated with $30 \%$ hydrogen peroxide $\left(\mathrm{H}_{2} \mathrm{O}_{2}\right)$ to remove the associated organic matter. This was done by adding $\mathrm{H}_{2} \mathrm{O}_{2}$ to the soil fractions at a $\mathrm{H}_{2} \mathrm{O}_{2}$ : suspension ratio of $1: 2$, acidifying to $\mathrm{pH} 2$ with $0.1 \mathrm{M} \mathrm{HCl}$, and heating at $60{ }^{\circ} \mathrm{C}$ for $16 \mathrm{~h}$ with stirring. The suspensions were neutralized by adding $\mathrm{NaOH}(0.1 \mathrm{M})$ and dialyzed (1000 kDa membrane) against deionized water to remove excess $\mathrm{H}_{2} \mathrm{O}_{2}$. To determine chemical reactivity, $\mathrm{C}$ and $\mathrm{N}$ contents were determined before and after the oxidation.

Electrophoretic mobility measurements were made at $25^{\circ} \mathrm{C}$ using a Zetasizer Nano ZS apparatus (Malvern Instruments) with a re-usable dip cell (Malvern EZ 1002). The associated software allowed zeta potentials to be derived from electrophoretic mobility data, using the Smoluchowski and Hückel equations (Hunter, 1981). Briefly, $1 \mathrm{mg}$ of the clay or nanoclay (before and after treatment with $\mathrm{H}_{2} \mathrm{O}_{2}$ ) was suspended in $1 \mathrm{~mL}$ of $0.001 \mathrm{M} \mathrm{KCl}$ by immersion in an ultrasonic bath for $5 \mathrm{~min}$. Measurements were carried out over a range of $\mathrm{pH}$ values (between 1 and 12), adjusted by careful addition of either $0.01 \mathrm{M} \mathrm{HCl}$ or $0.01 \mathrm{M} \mathrm{NaOH}$.

\subsection{Chemical characterization of soil organic matter}

The molecular composition of the SOM associated with the clay and nanoclay fractions were determined by analytical pyrolysis coupled with gas chromatography mass spectrometry (GC-MS), using samples that had been freeze-dried and ground to a fine powder. Curie -Point pyrolysis was carried out by heating the samples to the Curie-Point temperature of $650^{\circ} \mathrm{C}$. The pyrolysis products were analyzed by GC-MS, carried out with a pyrolysis unit (GSG Curie -Point Pyrolyser 1040 PSC) coupled to a gas chromatograph (Hewlett Packard HP 5890) and a mass spectrometer (Hewlett Packard HP 5889; electron energy $70 \mathrm{eV}$ ), using a polar silica capillary column. The temperature in the GC oven was raised from $30{ }^{\circ} \mathrm{C}$ to $250{ }^{\circ} \mathrm{C}$ at $4{ }^{\circ} \mathrm{C}$ per minute.

\subsection{Statistical analysis}

Data were analyzed by a multivariate analysis of variance (MANOVA), and comparisons were carried out for each pair with Tukey test by SPSS software (SPSS, Inc.) and the values were given as means \pm standard errors. Differences were considered significant when the $P$ value was less than or equal to 0.05 .

\section{Results}

3.1. Extraction yield and nanoclay size and morphology

Significantly more nanoclay could be extracted ( $p \leq$ 0.05 ) from Cambisols than from Andisols, amounting to $87.0 \pm 0.6$ and $88.5 \pm 1.5 \mathrm{~g} \mathrm{~kg}^{-1}$ soil for $\mathrm{CW}$ and $\mathrm{CM}$ 
respectively, while in Andisols recovery ranged $29.3 \pm 0.7$ and $55.3 \pm 0.5 \mathrm{~g} \mathrm{~kg}^{-1}$ soil for PN and $\mathrm{PEH}$, respectively.

Transmission electron microscopy (TEM) showed that nanoclays obtained from the two Andisols principally consisted of spherical aggregates of allophane with main diameter about $100 \mathrm{~nm}$ (Figure 1a, b). The nanoclays from the two Cambisols were crystalline nanoparticles according to observed in electron diffraction patterns with pseudohexagonal morphology (Figure 1c), typically reported for Kaolinite (Cravero et al., 1997; Qui et al., 2014). Their main size was $\sim 50 \mathrm{~nm}$ of external diameter (Figure 1d). TEM results showed that nanoclay fractions in the studied soils ranged from $100-50 \mathrm{~nm}$ and were smaller in Cambisol as compared to Andisol.

\subsection{Carbon and nitrogen content and C turnover}

The $\mathrm{C}$ and $\mathrm{N}$ content in bulk soil were higher in Andisols than Cambisols, ranging from $12.5 \pm 0.02$ to $106.2 \pm 1.1 \mathrm{~g}$ $\mathrm{kg}^{-1}$ for $\mathrm{C}$ and $1.9 \pm 0.4$ to $10.2 \pm 0.2 \mathrm{~g} \mathrm{~kg}^{-1}$ for $\mathrm{N}$ (Table 1). The nanoclay fractions in the two soil types were enriched in both $\mathrm{C}$ and $\mathrm{N}$ ( $p \leq 0.05$ ) with $41.4 \pm 0.6$ to $200.7 \pm 2.0 \mathrm{~g} \mathrm{C} \mathrm{kg}^{-1}$ and $5.5 \pm 0.2$ to $21.9 \pm 0.6 \mathrm{~g} \mathrm{~N} \mathrm{~kg}^{-1}$, for Cambisols and Andisols, respectively. The $\mathrm{C} / \mathrm{N}$ ratio of the nanoclay fractions did not differ from the bulk soils for both soil types under cropland, although $\mathrm{C} / \mathrm{N}$ ratios of the nanoclay fraction were lower compared to the bulk soil for the Andisol under grassland (Table 1).

The MRT of $\mathrm{C}$ was calculated for the Cambisol using stable $\mathrm{C}$ isotope ratios using the natural abundance tracing technique The MRT of nanoclays showed a turnover time of $135.7 \pm 10.5$ years; which was higher than for $\mathrm{C}$ in the bulk soil ( 94.8 years).

\subsection{Chemical reactivity}

After chemical oxidation, significant proportions ( $p \leq$ 0.05 ) of $\mathrm{C}$ and $\mathrm{N}$ were removed from nanoclays.
In general, highest $\mathrm{C}$ and $\mathrm{N}$ contents were recorded for nanoclays after chemical oxidation compared to all other fractions (data not shown). They ranged between $8.1 \pm 1.7$ to $65.2 \pm 0.7 \mathrm{~g} \mathrm{~kg}^{-1}$ for $\mathrm{C}$ and $2.5 \pm 0.4$ to $12.2 \pm 0.3 \mathrm{~g} \mathrm{~kg}^{-1}$ for $\mathrm{N}$. They were higher for nanoclay extracted from Andisols compared to Cambisols (Table 1).

The surface determinations showed that nanoclay from Cambisols had permanent negative charge (around $-35 \mathrm{mV}$ ) before and after chemical oxidation of organic matter, while Andisols had variable charge (Table 2). We found an isoelectric point (IEP) in nanoclays with organic matter of $3.4 \pm 0.2$ to $\mathrm{PN}$ and $2.2 \pm 0.7$ to $\mathrm{PEH}$, after chemical oxidation of organic matter the nanoclay showed an IEP of $5.1 \pm 0.6$ to PN and $5.4 \pm 1.2$ to $\mathrm{PEH}$.

\subsection{Chemical characterization of soil organic matter}

More pyrolysis products were released from bulk soil and nanoclay fractions of Andisols than Cambisols (Appendix A).

The results of the pyrolysis GC/MS analysis (Appendix A and Figure 2) showed that the most important compounds found in Andisol and Cambisol were released from aromatic compounds of unspecific origin (25 to $32 \%$ ), compared with $13-21 \%$ for polysaccharide-derived compounds and $15-42 \%$ for $\mathrm{N}$-containing compounds. The contribution of isoprenoid, lipid, black carbon and lignin-derived compound was generally lower (1-14\%).

In the Andisol fraction the pyrolysis products were chemically similar between bulk and nanoclay, while in Cambisols the nanoclay fractions did reveal higher contribution of N-containing compound respect to bulk, and lower lignin-derived and unspecific origin compounds. 
The black carbon content in Andisol fractions had higher relative contributions than in the Cambisol fractions, i.e. between 8 to $14 \%$ of relative abundance of $\mathrm{C}$ derived from black carbon for Andisols fractions compared with 4 to $6 \%$ for Cambisols

(Figure 2).

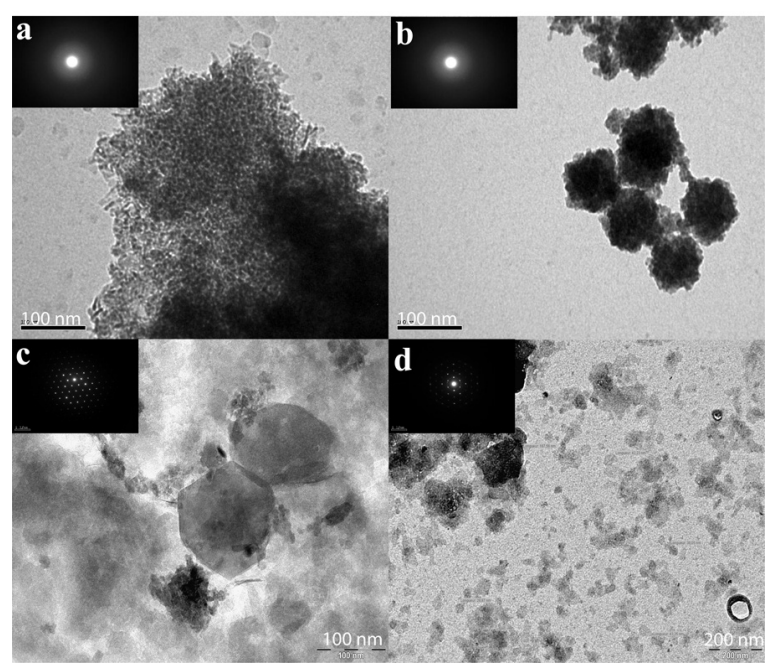

Figure 1. Transmission electron micrographs and electron diffraction patterns: (a) close-up of nanoclay Andisol; (b) nanoclay Andisol; (c) close-up of nanoclay Cambisol; and (b) nanoclay Cambisol.

Table 1. Mass recovery and $\mathrm{C}$ and $\mathrm{N}$ content before and after chemical oxidization of soil organic matter

\begin{tabular}{|c|c|c|c|c|c|c|c|c|c|c|c|c|c|}
\hline & \multirow{3}{*}{$\frac{\text { Mass }}{\left(\mathrm{g} \mathrm{kg}^{-1} \text { soil }\right)}$} & $\mathrm{C}$ & $\mathbf{N}$ & $\mathrm{C} / \mathrm{N}$ & $\mathrm{C}$ & $\mathbf{N}$ & $\delta^{13} \mathrm{C}$ & $\mathrm{C}$ & $\mathbf{N}$ & $\mathrm{C} / \mathrm{N}$ & $\mathrm{C}$ & $\mathbf{N}$ & $\mathrm{C}$ \\
\hline & & & & \multicolumn{3}{|c|}{ Untreated samples } & & & & \multicolumn{3}{|c|}{ Treated with $\mathrm{H}_{2} \mathrm{O}_{2}$} & \\
\hline & & \multicolumn{2}{|c|}{ ( $\mathrm{g} \mathrm{kg}^{-1}$ fraction) } & & \multicolumn{2}{|c|}{ Enrichment } & $(\%)$ & \multicolumn{2}{|c|}{ ( $\mathrm{g} \mathrm{kg}^{-1}$ fraction) } & & \multicolumn{2}{|c|}{ Enrichment } & $\%^{a}$ \\
\hline \multicolumn{14}{|c|}{ Andisol series Piedras Negras grassland } \\
\hline Bulk & 1000 & $98.2 \pm 0.3^{\mathrm{b}}$ & $7.9 \pm 0.1$ & 12.4 & & & $-27.3 \pm$ n.d. $^{\mathrm{c}}$ & $25.4 \pm 1.4$ & $4.6 \pm 0.3$ & 5.6 & & & 26 \\
\hline Nanoclay & $29.3 \pm 0.7$ & $200.7 \pm 2.0$ & $21.9 \pm 0.6$ & 9.2 & $2.0 \pm 0.0$ & $2.8 \pm 0.1$ & $-26.3 \pm 0.1$ & $65.2 \pm 0.7$ & $12.2 \pm 0.3$ & 5.4 & $2.6 \pm 0.2$ & $2.7 \pm 0.2$ & 32 \\
\hline \multicolumn{14}{|c|}{ Andisol series Pemehue wheat } \\
\hline Bulk & 1000 & $106.2 \pm 1.1$ & $10.2 \pm 0.2$ & 10.4 & & & $-26.6 \pm$ n.d. & $34.7 \pm 0.1$ & $4.5 \pm 0.2$ & 7.7 & & & 33 \\
\hline Nanoclay & $55.3 \pm 0.5$ & $190.8 \pm 1.9$ & $18.6 \pm 1.3$ & 10.2 & $1.8 \pm 0.1$ & $1.8 \pm 0.1$ & $-25.8 \pm 0.2$ & $45.6 \pm 0.2$ & $10.1 \pm 0.3$ & 4.5 & $1.3 \pm 0.1$ & $2.3 \pm 0.1$ & 24 \\
\hline \multicolumn{14}{|c|}{ Eum Cambisol 9 year maiz } \\
\hline Bulk & 1000 & $13.7 \pm 0.2$ & $2.1 \pm 0.1$ & 6.7 & & & $-25.9 \pm$ n.d. & $3.9 \pm 0.2$ & $1.1 \pm 0.1$ & 3.4 & & & 28 \\
\hline Nanoclay & $88.5 \pm 1.5$ & $38.2 \pm 0.2$ & $5.5 \pm 0.2$ & 7.0 & $2.8 \pm 0.0$ & $2.8 \pm 0.8$ & $-25.6 \pm 0.1$ & $9.7 \pm 0.8$ & $3.7 \pm 0.1$ & 2.6 & $2.5 \pm 0.5$ & $2.4 \pm 0.7$ & 25 \\
\hline \multicolumn{14}{|c|}{ Eum Cambisol only wheat } \\
\hline Bulk & 1000 & $12.5 \pm 0.2$ & $1.9 \pm 0.4$ & 6.7 & & & $-24.4 \pm$ n.d. & $3.8 \pm 0.1$ & $1.1 \pm 0.1$ & 3.4 & & & 30 \\
\hline Nanoclay & $87.0 \pm 0.6$ & $41.4 \pm 0.6$ & $5.6 \pm 0.1$ & 7.4 & $3.3 \pm 0.1$ & $3.1 \pm 0.4$ & $-24.5 \pm 0.1$ & $8.1 \pm 1.7$ & $2.5 \pm 0.4$ & 3.2 & $2.2 \pm 0.4$ & $2.3 \pm 0.3$ & 20 \\
\hline
\end{tabular}

\footnotetext{
a Percentage of total $\mathrm{C}$, calculated as [C (Treated with $\left.\mathrm{H}_{2} \mathrm{O}_{2}\right) \times 100 / \mathrm{C}$ (Untreated samples)]

${ }^{\mathrm{b}}$ Media \pm standard error

${ }^{\mathrm{c}} \mathrm{n} \cdot \mathrm{d}=$ not determined, single measurement only
} 


\section{Discussion}

\subsection{Nanoclay extraction yields and morphology}

Cambisols nanoclay was extracted with fewer washing steps than Andisols (5 instead of 11). Despite the faster extraction procedure, nanoclay yields were significantly higher $(p \leq 0.05)$ for Cambisols than Andisols (Table 1), comprising around $90 \mathrm{~g}$ nanoclay $\mathrm{kg}^{-1}$ soil, while for Andisols we recovered between $29.3 \pm 07$ and $55.3 \pm 0.5 \mathrm{~g}$ nanoclay $\mathrm{kg}^{-1}$ soil (Table 1). Thus, between 54 to $56 \%$ of clay fraction in Cambisols is nanoclay, in line with results reported by Eusterhues et al. (2005).

In Andisols, the nanoclay contribution to the clay fraction ranged between 22 to $28 \%$. This is in contrast to the theoretical content of nanomaterials in Chilean Andisols, which is much higher with quoted values of around 117 and $72 \mathrm{~g}$ nanoclay $\mathrm{kg}^{-1}$ soil for $\mathrm{PN}$ and PEH, respectively (only considering allophane and ferrihydrite content reported by Vistoso et al., 2009). Transmission electron microscopy (TEM) showed that the nanoclay from Andisols were larger than nanoclay from Cambisols, consisting of spherical aggregates of allophane with a diameter of about $100 \mathrm{~nm}$ (Figure 1b). Chevallier et al. (2010) found similar results for Andisols and suggested that intimate association of OM and minerals through aggregation at small scale is an important mechanism for C stabilization in Andisols.

The TEM images of nanoclay from Cambisol showed that the methodology proposed by Calabi-Floody et al. (2011) was useful for nanoclay extractions also from this soil type. In contrast to nanoclay from Andisol, the one which was extracted from Cambisol was smaller and contrasting morphology, indicating crystalline pseudohexagonal nanoclays with mainly size $\sim 50 \mathrm{~nm}$ of external diameter (Figure 1c), commonly described for kaolinite (Cravero et al., 1997;
Qui et al., 2014). The differences in the morphology and the sizes of the nanoclays obtained could be explained by the nature of the organo-mineral interactions operating in both soil types. In Andisols there are strong interactions between OM and allophane, due to low permeability of the fractal allophane aggregate (Huygens et al., 2005; Chevallier et al., 2010), as well as Al-Fe-Humic complexes (Mora and Canales, 1995a; Dahlgren et al., 2004; Matus et al., 2014). These strong interactions generate an incomplete disruption of organo-mineral complexes leading to larger size of nanoclay fractions isolated from Andisols than Cambisols. The allophane aggregate formation may also be the reason for the lower extraction yields. Thus, higher levels of dispersion are required for Andisols compared to Cambisols to achieve complete aggregate dispersion (Asano and Wagai, 2014). It is widely accepted that nanoparticles have different properties respect to its bulk material, becoming highly interesting at industrialist level (Patel et al., 2006; Haider and Kang, 2015), their potentiality in nanotechnology have been proposed as a key role in the current society (Qian and Hinestroza, 2004), and is one of the most important tools in modern agriculture (Sekhon, 2014). For example, nanoparticles were recently reported to be potentially useful carrier for enzymes and could be used for fertilizer development (Calabi-Floody et al., 2012; Menezes-Blackburn et al., 2014), to control nitrate (Cai et al., 2014) and pesticide migration (Xiang et al., 2014).

According our results, we suggested that in terms of extraction, nanoclays from Cambisols could be more interesting for future nanotechnological applications, due to faster and easily nanoclay extraction procedure and much larger yield, while nanoclays from Andisols could be interesting in terms of higher reactivity of he allophane. 
Table 2. Zeta potentials as a function of suspension $\mathrm{pH}$ for nanoclays before and after peroxide treatment. Determination of isoelectric point and surface charge

\begin{tabular}{|c|c|c|c|c|}
\hline & \multicolumn{2}{|c|}{ Untreated samples } & \multicolumn{2}{|c|}{ Treated with $\mathrm{H}_{2} \mathrm{O}_{2}$} \\
\hline & $\begin{array}{l}\text { IEP } \\
(\mathrm{pH}) \\
\end{array}$ & $\begin{array}{c}\text { Zeta-potential }^{\mathrm{a}} \\
(\mathrm{mV})\end{array}$ & $\begin{array}{l}\text { IEP } \\
(\mathrm{pH}) \\
\end{array}$ & $\begin{array}{c}\text { Zeta-potential }^{\mathrm{a}} \\
(\mathrm{mV})\end{array}$ \\
\hline $\begin{array}{l}\text { Andisol series Piedras Negras grassland } \\
\text { Nanoclay }\end{array}$ & $3.4 \pm 0.2^{b}$ & 0 to $-26 \pm 3$ & $5.1 \pm 0.6$ & 0 to $-13 \pm 6$ \\
\hline $\begin{array}{l}\text { Andisol series Pemehue wheat } \\
\text { Nanoclay }\end{array}$ & $2.2 \pm 0.7$ & 0 to $-27 \pm 3$ & $6.4 \pm 1.2$ & 0 to $-15 \pm 5$ \\
\hline $\begin{array}{l}\text { Eum Cambisol } 9 \text { year maiz } \\
\text { Nanoclay }\end{array}$ & - & $-35 \pm 2$ & - & $-31 \pm 1$ \\
\hline $\begin{array}{l}\text { Eum Cambisol only wheat } \\
\text { Nanoclay }\end{array}$ & - & $-37 \pm 1$ & - & $-31 \pm 2$ \\
\hline
\end{tabular}

${ }^{a}$ For Andisols the charge reported were after IEP and for Cambisols the main charge were reported

${ }^{\mathrm{b}}$ Media \pm standard error

\subsection{Carbon and nitrogen content}

In the nanoclay fractions extracted from both soils, we observed an enrichment of C compared with bulk soil, around 2-fold for allophanic nanoclays and more than 3-fold for kaolinite nanoclays. Their $\mathrm{C}$ content ranged between 20 and 4\% for Andisols and Cambisols (Table 1). These results are in line with those reported by Mikutta et al. (2005), Calabi-Floody et al. (2011) and Asono and Wagai (2014), all suggested a possible important role of nanoclay for $\mathrm{C}$ sequestration and stabilization independent of soil type. While the smallest particle size fraction $(0-2 \mu \mathrm{m})$ containing high amounts of iron oxides was found to be important for $\mathrm{C}$ sequestration, due to stable organic-mineral associations in Cambisols (Mikuta et al., 2005; Eusterhues et al., 2005; Kögel-Knabner et al., 2008). Nano materials $(<100 \mathrm{~nm})$ have been recently identified as being potentially important for $\mathrm{C}$ sequestration in $\mathrm{C}$ rich soils such as Andisols (Chevallier et al., 2010; Calabi-Floody et al., 2011; Hernández and Almendros, 2012) and Mollisols (Monreal et al., 2010).
Nanoclays may be important for soils C storage because of their high surface area, surface reactivity and their associated properties such as adsorbing or binding to organic and trace metal contaminants (Tsao et al., 2013). However, allophanic nanoclays showed a significantly higher $\mathrm{C}$ and $\mathrm{N}$ content than kaolinitic nanoclays, around 5-fold more $\mathrm{C}$ and 3-fold more N (Table 1).

These differences could be explained due to higher specific surface area of short-range-order minerals content of Andisols compared to Cambisols (Saggar et al., 1994; Chevallier et al., 2008; 2010) and their observed behavior as natural gels (Woignier et al., 2006; Chevallier et al., 2008; 2010). Therefore, in the nanoclay fraction of Andisols most probably OM is protected from microbial decay by physico-chemical mechanisms in the pore structure of Andisols. To determine if the nanoclay fraction is also important for SOM stabilization in Cambisols both soils were also subjected to chemical oxidation, which is known to isolated old stabilized SOM (Eusterhues et al., 2005). 


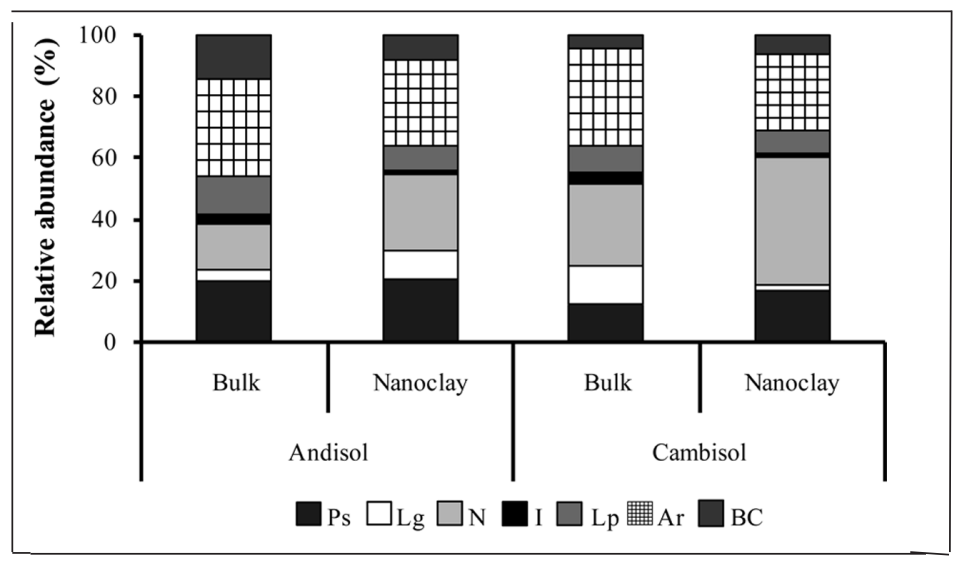

Figure 2. Total relative abundance of the different group of identified pyrolysis products on the bulk and nanoclay from Andisol and Cambisol. Where; Ps: Compound derived from polysaccharides, Lg: Compound derived from lignin, N: N-containing compounds, I: Isoprenic compounds, Lp: Compound derived from lipids, Ar: Aromatic compound and $\mathrm{BC}$ : Black carbon

\subsection{Chemical oxidation and C stabilization}

After chemical oxidation, the $\mathrm{C}$ and $\mathrm{N}$ contents were significantly reduced $(p \leq 0.05)$. Hydrogen peroxide removed between 67 and $80 \%$ of $\mathrm{C}$ and 33 to $56 \%$ of $\mathrm{N}$ (Table 1). Both soil showed similar losses and bulk soils were not different from the nanoclay fractions.

After $\mathrm{C}$ chemical oxidation of soil fractions, the significant influence of nanoclay fractions on $\mathrm{C}$ stabilization clearly was observed (Table 1). The nanoclay fractions from Andisols were C enriched 2.6-fold for PN and 1.3 for PEH respect to bulk soils. The nanoclay from Cambisols showed $\mathrm{C}$ enrichment around 2-fold. The $\mathrm{N}$ content after $\mathrm{H}_{2} \mathrm{O}_{2}$ treatments were also enriched in nanoclay fractions around 2.5-fold suggesting that aromatic nitrogen compounds are involved in $\mathrm{C}$ sequestration.

The SOM oxidation released active sites on nanoclays surface thereby increasing the IEP values to the typical allophane and iron oxide coating as discussed by Mora and Canales (1995b). Furthermore, the high IEP values of nanoclays from $\mathrm{PEH}$ treated with $\mathrm{H}_{2} \mathrm{O}_{2}$ indicated that $\mathrm{C}$ was less stabilized than in PN nanoclays fraction. On the contrary, the low IEP in PN nanoclays fraction after $\mathrm{C}$ chemical oxidation suggesting that fraction. On the contrary, the low IEP in PN nanoclays fraction after C chemical oxidation suggesting that he allophane (Al)humus complexes are able to stabilize more $\mathrm{C}$ in this Andisol (Mora and Canales 1995a). In both Cambisols we observed a trend to reduce the negativity of zeta potential with $\mathrm{C}$ chemical oxidation, these results are in agreement with our results of the $\mathrm{C}$ with the same content being removed from these soils (see Table 1). The nanoclay fraction plays an important role in $\mathrm{C}$ stabilization in Andisols (Chevallier et al., 2010, Calabi-Floody et al., 2011; Kögel-Knabner and Amelung. 2014). Taking account, the results presented in Table 1 we observed a higher amount of remained $\mathrm{C}$ in PN than PEH nanoclays. Vistoso et al. (2009) reported that allophane content was around 2-fold higher in PN $\left(96.50 \pm 0.45 \mathrm{~g} \mathrm{~kg}^{-1}\right)$ than PEH $\left(54.60 \pm 0.44 \mathrm{~g} \mathrm{~kg}^{-1}\right)$, instead that ferrhydrite content was similar for both soils (20.20 \pm 0.60 and $17.50 \pm 0.70 \mathrm{~g} \mathrm{~kg}^{-1}$, respectively). These results may suggest that the presence of allophane does play a leading role of $\mathrm{C}$ stabilization in Andisols. 
These findings agree with data reported by Mikutta $\mathrm{el}$ al. (2005) who found that surface complexation between mineral surface hydroxyls and carboxylic These results may suggest that the presence of allophane does play a leading role of $\mathrm{C}$ stabilization in Andisols. These findings agree with data reported by Mikutta el al. (2005) who found that surface complexation between mineral surface hydroxyls and carboxylic group of OM was the main mechanism for $\mathrm{C}$ stabilization and poorly crystalline minerals explained $84 \%$ of the variability of stable $\mathrm{C}$ in fine clay fractions.

Our data indicated that also in Cambisols the $\mathrm{C}$ stabilization was mainly attributed to nanoclay (Table 1). These results could be explained by the adsorption of strongly humified organic material to the smallest soil particles (Rumpel et al., 2004). The MRT calculated for nanoclays (135.7 \pm 10.5 years) from Cambisols was higher than for bulk soil of 94.8 years, suggesting that it takes longer to replace $\mathrm{C}$ present in the nanoclay fraction compared to bulk soil. These values are much lower than what was generally reported for mineral associated stable soil $\mathrm{C}$, which can have MRTs up to several thousand years (e.g. Moni et al., 2010). However, these 'stable' compounds are rarely found in topsoils (Bol et al., 2009). Our data suggest that association of SOM to nanoclay may have the potential to lower $\mathrm{C}$ turnover of topsoil in the range of several decades.

\subsection{Chemical characterization of nanoclay associated SOM}

Organo-mineral complexes were studied by pyrolysis, the pyrolysates produced by soils fractions from Andisols were richer pyrolyzable material than those from the Cambisols (Appendix A). Similar results were shown by González-Pérez et al. (2007) for bulk soil samples.

The pyrolysis analysis (Figure 2) in general showed that the studied soils were enriched in compounds from unspecific origin, polysaccharide-derived and
$\mathrm{N}$-containing compounds. The relative abundance of pyrolysis compound showed no difference chemical nature between nanoclay and bulk fractions, while in Cambisols, the nanoclay fraction showed a higher relative abundance of $\mathrm{N}$-derived compounds than bulk. More than $50 \%$ of $\mathrm{N}$-containing compounds of this soil were benzoxazoles and long-chain alkyl nitriles (Appendix A), which appear to be soil specific (Schulten and Schnitzer, 1998). Pyridines were the next abundant group in $\mathrm{N}$-containing compounds for Cambisols. In particular, pyridines have been reported to be derived from microbial decomposition of plant lignins and other phenolics in the presence of $\mathrm{NH}_{3}$ (Schulten and Schnitzer, 1998; Buurman et al., 2007), they but could also be pyrolysis products of chlorophyll (Dignac et al., 2005, Gonzalez-Perez et al., 2007, Buurman et al., 2007). In Andisols, the $\mathrm{N}$-containing compounds contributing were mainly derived from pyridines and pyrroles (Appendix A). Pyrroles can be derived from plant proteins and substituted pyrroles are formed readily through porphyrin pyrolyzes, which is an essential component of the chlorophyll (Bracewell et al., 1987; in Schulten and Schnitzer, 1998). This could indicate that the nanoclay fraction contains transformed plant derived compounds rather than microbial products. This hypothesis is supported by the high contribution of unspecific compounds in Andisol fractions; showing that nanoclay associated SOM compounds could be more recalcitrant. The benzene and phenols are commonly formed upon pyrolysis of large macromolecules such as organo-complexes, lignins and tannins. The phenolic and carboxylic group present in these compounds may be responsible for the high functional group content of this fraction, which could be make it used for biotechnological applications. Parfitt et al. (1999) and Nierop et al. (2005) suggest that polysaccharides may be temporarily stabilized by the presence of allophane, explained the high abundance relative in these 
soil fractions. The molecular chemistry of the organic fractions indicates a strong decomposition of plantderived organic matter and a strong contribution of microbial sugars and $\mathrm{N}$-compounds to soil organic C (Schulten and Schnitzer, 1998; Buurman et al, 2007). The findings of this study indicate a relatively higher contribution of $\mathrm{BC}$ in nanoclay fraction from Andisols. The small differences observed in BC content on the different Andisol fractions (Figure 2) could be attributed to the fact that the stable $\mathrm{C}$ in Andisol was mainly in the nanoclay fraction due to high allophane content (Chevallier et al., 2010; Calabi-Floody et al., 2011), which have strong organo-mineral interactions (Mora and Canales, 1995a; Chevallier et al., 2010; Calabi-Floody et al., 2011; Rumpel et al., 2012; Matus et al., 2014). Moreover, BC compounds in soil are known to be stabilized by interaction with minerals (Brodowski et al., 2005, Rumpel et al., 2012), contributing to the long-term soil C storage (Rumpel et al., 2008). In Cambisol (Figure 2), we did not observe a strong influence of nanoclay fractions on the $\mathrm{BC}$, considering that around $50 \%$ of clay fraction corresponds to nanoclay fraction. The results showed a trend of a direct correlation of $\mathrm{BC}$ content with size fractions. This could be attributed to the mineralogy of the Cambisol. These results are in accordance with the weak organo-mineral interactions observed in the soil fractionation and facilitation of the nanoclay extractions in Cambisols.

\section{Conclusions}

Nanoclay fractions from both soil types have contrasting characteristics in terms of size, morphology, organic matter content, composition as well as surface reactivity. However, overall chemical composition of SOM was similar for both soil types, highlighting the importance of nanoclay fraction for $\mathrm{C}$ stabilization. Stable isotope analyses indicated a decadal stabilization for SOM associated with nanoclay isolated from
Cambisol topsoil, which did not show a strong aggregation of the nanoclay fraction. For Andisol, the C stabilization potential may be higher in Andisol due to the spatial arrangement of minerals and SOM in nanosize structures, which could be efficient in contributing to the long-term soil $\mathrm{C}$ storage.

The applied nanoclay extraction methodology was more suitable for Cambisols than for Andisols, indicated by faster and easily nanoclay extraction and much larger yield obtained ( $\sim 50 \%$ of clay fraction). Low nanoclay yields for Andisols did show that it is necessary to further improve the nanoclay extraction procedure for this soil type considering the potential of allophanic nanoclay for use in future nanotechnological and biotechnological applications (CalabiFloody et al., 2009, 2012; Garrido-Ramirez et al., 2010; Menezes-Blackburn et al., 2011).

\section{Acknowledgments}

We gratefully acknowledge Comisión Nacional de Investigación Científica y Tecnológica (CONICYT) for financial support under CONICYT, FONDECYT/Postdoctorado $N^{\circ} 3120157$ from Chilean Government. We also acknowledge financial support from the European Science foundation under the framework of the MOLTER program. The authors gratefully thank at colleagues form Scientific and Technological Bioresource Nucleus (BIOREN) from La Frontera University, and Laboratoire de Biogéochimieet Ecologie des Milieux Continentaux (BIOEMCO) Campus AgroParisTech, ThivervalGrignon, France, for their assistance and technical support. We also acknowledge ECOSSUD-CONICYT C08U01 and C13U02 for their financial support to encourage collaboration between French and Chilean research groups. 


\section{References}

Asano, M., Wagai, R. 2014. Evidence of aggregate hierarchy atmicro-to submicron scales in an allopphanic Andisol. Geoderma. 216, 62-74.

Bahri, H., Dignac, M.F., Rumpel, C., Rasse. D.P., Chenu, C., Mariotti, A. 2006. Lignin turmover kinetics in an agricultural soil is monomer specific. Soil Biol.Biochem. 38, 1977-1988.

Batjes, N.H. 1996. Total carbon and nitrogen in thesoils of the world. Eur. J. Soil Sci. 47, 151-163.

Bol, R. Gleixner, G., Poirier, N, Balesdent, J., 2009. Molecular turnover time of SOM in particle size fractions of an arable soil. Rapid. Commun. Mass. Sp. 23, 2551-2558.

Bracewell, J.M. Pacey, N., Robertson, G.W., 1987. Organic matter in onshore Cretaceous chalks and its variations, investigated by pyrolysis-mass spectrometry.J. Anal. Appl. Pyrol. 10, 199-213.

Brodowski. S.,Amelung, W., Haumaier, L., Abetz, C., Zech, W., 2005. Morphological and chemical properties of black carbon in physical soil fractions as revealed by scanning electron microscopy and energy-dispersive X-ray spectroscopy. Geoderma. 128, 116-129.

Buurman, P., Peterse, F., Almendros Martin, G. 2007. Soil organic matter chemistry in allophanic soils: a pyrolysis-GC/MS study of a Costa Rican Andosol catena. Eur. J. Soil Sci. 58, 1330-1347.

Cai, D., Wu, Z., Jiang, J., Wu, Y., Feng, H., Brown, I.G., Chu, P.K., Yu, Y. 2014.Controlling nitrogen migration through micro-nano networks. Scientific Reports. 4: 3665, 1-8.

Calabi-Floody, M., Velásquez, G., Gianfreda, L., Saggar, S., Bolan, N., Rumpel, C., Mora, M.L. 2012. Improving bioavailability of phosphorous from cattle dung by using phosphatase immobilized on natural clay and nanoclay. Chemophere. 89, 644-655.
Calabi-Floody, M., Bendall, J.S., Jara, A.A., Welland, M.E., Theng, B.K.G., Rumpel, C., Mora, M.L. 2011. Nanoclays from an Andisol: Extraction, properties and carbon stabilization. Geoderma 161, 159-167.

Calabi-Floody, M., Theng, B.K.G., Reyes, P., Mora, M.L. 2009. Natural nanoclays: applications and future trends - a Chilean perspective. Clay Miner. 44, 161-176.

Chevallier, T., Woignier, T., Toucet, J., Blanchart, E., 2010. Organic carbon stabilization in the fractal pore structure of Andosols. Geoderma. 159,182188.

Chevallier, T., Woignier, T., Toucet, J., Blanchart, E., Dieudonné, P., 2008. Fractal structure in natural gels: effect on carbon sequestration in volcanic soils. J. Sol-Gel Sci. Techn. 48 (1-2), 231-238.

Cravero, F., Gonzalez, I., Galan, E. , Dominguez, E., 1997. Geology, mineralogy, origin and possible applications of some Argentinian kaolins in the Neuquen basin. Appl. Clay. Sci. 12, 27-42

Dahlgren, R.A., Saigusa, M., Ugolini, F.C., 2004. The nature, properties and management of volcanic soils. Adv. Agron. 82, 113-182.

Dignac, M.F., Bahri, H., Rumpel, C., Rasse, D.P., Bardoux, G., Balesdent, J., Girardin, C., Chenu, C., Mariotti, A., 2005. Carbon-13 natural abundance as a tool to study the dynamics of 7 lignin monomers in soil: an appraisal at the Closeaux experimental field (France). Geoderma 128, 3-17.

Eusterhues, K., Rumpel, C., Kögel-Knabner, I. 2005. Organo-mineral associations in sandy acid forest soils: importance of specific surface area, iron oxides and micropores. Eur. J. Soil Sci. 56, 753-763.

FAO, 2001. "World Soil Resources Reports" In: Driessen, P. Deckers, J. (Eds), Lecture Notes on the Major Soils of the World. Rome, pp 
Haider, A., Kang, I.K. 2015. Preparation of Silver Nanoparticles and Their Industrial and Biomedical Applications: A Comprehensive Review. Adv. Mater. Sci. Eng. 2015, 1-16.

Hernández, Z., Almendros, G. 2012. Biogeochemical factors related with organic matter degradation and $\mathrm{C}$ storage in agricultural volcanic ash soils. Soil Biol. Biochem. 44, 130-142.

Hiemstra, T., Antelo, J., van Rotterdam, A.M.D. (Debby), van Riemsdijk, W.H. 2010. Nanoparticles in natural systems II: The natural oxide fraction at interaction with natural organic matter and phosphate. Geochim.Cosmochim. Ac. 74, 59-69.

Hunter, R.J., 1981. Zeta Potential in Colloid Science. Academic Press, London.

Huygens, D., Boeckx, P., Van Cleemput, O., Oyarzun, C., Godoy, R. 2005. Aggregate and soil organic carbon dynamics in South Chilean Andisols. Biogeosciences. 2, 159-174.

Khedr, M.H., Omar, A.A., Abdel-Moaty, S.A. 2006. Reduction of carbon dioxide into carbon by freshly reduced $\mathrm{CoFe} 2 \mathrm{O} 4$ nanoparticles. Mater. Sci. Eng. A. 432, 26-33.

Kögel-Knabner, I., Amelung, W. 2014. Dynamics, Chemistry, and Preservation of Organic Matter in Soils. In: Falkowski, P.G., Freeman, K.H. (Eds), Treatise on Geochemistry (Second Edition). Elsevier Ltd. Chapter 7. Volume 12: Organic Geochemistry, pp: 157-215.

Kögel-Knabner, I., Guggenberger, G., Kleber, M., Kandeler, E., Kalbitz, K., Scheu, S., Eusterhues, K., Leinweber, P. 2008. Organo-mineral associaltions in temperate soils: integrating biology, mineralogy and organic matter chemistry. J. Plant. Nutr. Soil Sci. 171, 61-82.

Lal, R., 2010. Terrestrial sequestration of carbon dioxide $\left(\mathrm{CO}_{2}\right)$ pp 217-298. In: Maroto-Valer, M. (Ed.), Developments and innovation in carbon dioxide $\left(\mathrm{CO}_{2}\right)$ capture and storage technology.
Volume 2: Carbon dioxide $\left(\mathrm{CO}_{2}\right)$ storage and utilisation. Wood head Publishing Limited, 2010.

Matus, F., Rumpel, C., Neculman, R., Panichini, M., Mora, M.L. 2014. Soil carbon storage and stabilisation in andic soils: A review. Catena. 120, 102-110.

Mella, A., Kühne, A. 1985. Sistemática y descripción de las Familias, Asociaciones y Series de Suelos derivados de materiales piroclásticos de la Zona Central-Sur de Chile. In: Tosso, J. (Ed.), Suelos volcánicos de Chile. INIA-Minagri. Santiago, Chile. pp: 548-716.

Menezes-Blackburn, D., Jorquera, M., Gianfreda, L., Rao, M., Greiner, R., Garrido, E., Mora, M.L., 2011. Activity stabilization of Aspergillus niger and Escherichia coli phytases immobilized on allophanic synthetic compounds and montmorillonite nanoclays. Bioresource Technol. 102 (20), 9360-9367.

Menezes-Blackburn, D., Jorquera, M.A., Gianfreda, L., Greiner, R., Mora, M.L. 2014. A novel phosphorus biofertilization strategy using cattle manure treated with phytase-nanoclay complexes. Biol. Fertil. Soils. 50, 583-592.

Mikutta, R., Kleber, M., Jahn, R. 2005. Poorly crystalline minerals protect organic carbón in clay subfractions from acid subsoil horizons. Geoderma. 128 (1-2), 106-115.

Moni, C., Chabbi, A., Nunan, N., Rumpel, C., Chenu, C. 2010. Spatial dependance of organic carbon-metal relationships A multi-scale statistical analysis, from horizon to field. Geoderma. 158, 120-127.

Monreal, C.M., Sultan, Y., Schnitzer, M. 2010. Soil organic matter in nano-scale structures of a cultivated Black Chernozem. Geoderma. 159, 237-242.

Mora, M.L., Canales, J. 1995a. Humin- clay interactions on surface reactivity in Chilean Andisols.Commun. Soil Sci. Plant Anal. 26(17-18), 2819-2828. 
Mora, M.L., Canales, J. 1995b. Interactions of humic substances with allophanic compounds. Commun. Soil Sci. Plant Anal. 26, 2805-2817.

Nierop, K.G.J., van Bergen, P.F., Buurman, P., van Lagen, B. 2005. $\mathrm{NaOH}$ and $\mathrm{Na}_{4} \mathrm{P}_{2} \mathrm{O}_{7}$ extractable organic matter in two volcanic ash soils of the Azores Islands - a pyrolysis GC/MS study. Geoderma. 127, 36-51.

Pan, B., Xing, B. 2012. Applications and implications of manufactured nanoparticles in soils: a review. Eur. J. Soil Sci. 63, 437-456.

Parfitt, R.L., Russell, M., Orbell, G.E. 1983. Weathering sequence of soils from volcanic ash involving allophane and halloysite, new zealand. Geoderma. 29, 41-57.

Parfitt, R.L., Yuan, G., Theng, B.K.G. 1999. A 13CNMR study of the interactions of soil organic matter with aluminium and allophane in podzols. Eur. J. Soil Sci. 50, 695-700.

Patel, H.A., Somani, R.S., Bajaj H.C., Jasra, R.V. 2006. Nanoclays for polymer nanocomposites, paints, inks, greases and cosmetics formulations, drug delivery vehicle and waste water treatment. B. Mater. Sci. 29, 133-145.

Qian, L., Hinestroza, J.P. 2004. Application of nanotechnology for high performance textiles. J. Text. Appar. Technol. Manag. 4:1, 1-7.

Qiu, X., Lei, X., Alshameri, A., Wang, H., Yan, C., 2014. Comparison of the physicochemical properties and mineralogy of Chinese (Beihai) and Brazilian kaolin. Ceram. Int. 40, 5397-5405.

Regelink, I.C., Weng, L., Koopmans, G.F., van Riemsdijk, W.H. 2013. Asymmetric flow fieldflow fractionation as a new approach to analyse iron-(hydr)oxide nanoparticles in soil extracts. Geoderma. 202-203, 134-141.
Rumpel, C., Rodríguez-Rodríguez, A., GonzálezPérez, J.A., Arbelo, C., Chabbi, A., Nunan, N., González-Vila, F.J. 2012. Contrasting composition of free and mineral-bound organic matter in top and subsoil horizons of Andosols. Biol. Fertil. Soils. 48, 401-411.

Rumpel, C., Chaplot, V., Chabbi, A., Largeau, C., Valentin, C. 2008. Stabilisation of HF soluble and $\mathrm{HCl}$ resistant organic matter in tropical sloping soils under slash and burn agriculture. Geoderma $145,347-354$.

Rumpel, C., Eusterhues, K., Kögel-Knabner, I. 2004. Location and chemical composition of stabilized organic carbon in topsoil and subsoil horizons of two acid forest soils. Soil Biol. Biochem. 36, 177-190.

Saggar, S., Tate, K.R., Feltham, C.W., Childs, C.W., Parshotam, A. 1994. Carbon turnover in a range of allophanic soils amended with 14C-labelled glucose. Soil Biol. Biochem. 26, 1263-1271.

Schulten, H.-R., Schnitzer M. 1998. The chemistry of soil organic nitrogen: a review. Biol. Fert. Soils $26,1-15$.

Sekhon, B.S. 2014. Nanotechnology in agri-food production: an overview. Nanotechnol. Sci. Appl. 2014:7, 31-53

Tsao, T., Chen, Y., Sheu, H., Tzou, Y., Chou, Y., Wang, M. 2013. Separation and identification of soil nanoparticles by conventional and synchrotron X-ray diffraction. Appl. Clay Sci. 85, 1-7.

Vistoso, E.M., Bolan, N.S., Theng, B.K.G., Mora, M.L. 2009. Kinetics of molybdate and phosphate sorption by some Chilean Andisols. J. Soil Sc. Plant Nutr. 9 (1), 55-68.

Wada, K., Kakuto, Y., Muchena, F.N., 1987. Clay minerals and humus complexes in five kenyan 
soils derived from volcanic ash. Geoderma. 39, 307-321.

Woignier, T., Primera, J., Ashmy, A. 2006. Application of the Diffusion Limited Cluster Agregation Model to natural gels: the allophanic soils. J. SolGel Sci. Techn. 40 (2-3), 201-207.
Xiang, Y., Wang, M., Sun, X., Cai, D., Wu, Z., 2014. Controlling Pesticide Loss through Nanonetworks. ACS Sustainable Chem. Eng. 2, 918-924.

Appendix A. Relative abundance of different classes of identified main pyrolysis products on the different soil fractions from Andisols and Cambisols. Where; Ps: Compound derived from polysaccharides, Lg: Compound derived from lignin, N: Ncontaining compounds, I: Isoprenic compounds, Lp: Compound derived from lipids, Ar: Aromatic compound and BC: Black carbon. The peak areas were calculated based on total abundance, considering the summation of the areas of all peaks as $100 \%$ of the total ion chromatogram.

\begin{tabular}{|c|c|c|c|c|c|c|c|}
\hline \multirow{3}{*}{ Compound } & \multirow{3}{*}{ Code } & \multicolumn{2}{|c|}{ Molecular } & \multicolumn{2}{|c|}{ Andisol } & \multicolumn{2}{|c|}{ Cambisol } \\
\hline & & Formula & Weight & Bulk & Nanoclay & Bulk & Nanoclay \\
\hline & & & & \multicolumn{4}{|c|}{ Relative abundance (\%) } \\
\hline Furan, 2-methyl- & Ps1 & $\mathrm{C}_{5} \mathrm{H}_{6} \mathrm{O}$ & 82 & - & 1.2 & - & 2.5 \\
\hline Furan, 3-methyl- & Ps2 & $\mathrm{C}_{5} \mathrm{H}_{6} \mathrm{O}$ & 82 & 2.9 & - & 2.7 & - \\
\hline Furan, 2,5-dimethyl- & Ps3 & $\mathrm{C}_{6} \mathrm{H}_{8} \mathrm{O}$ & 96.1 & 1.4 & 0.8 & 1 & 0.7 \\
\hline 2,3,5-Trimethylfuran & Ps4 & $\mathrm{C}_{7} \mathrm{H}_{10} \mathrm{O}$ & 110.1 & 0.3 & - & 0.2 & 0.2 \\
\hline 2-Vinylfuran & Ps5 & $\mathrm{C}_{6} \mathrm{H}_{6} \mathrm{O}$ & 94 & - & - & - & 0.5 \\
\hline 2-Vinyl-5-methylfuran & Ps6 & $\mathrm{C}_{7} \mathrm{H}_{8} \mathrm{O}$ & 108.1 & 0.8 & - & - & - \\
\hline Furan, 2-ethyl- & Ps 7 & $\mathrm{C}_{6} \mathrm{H}_{8} \mathrm{O}$ & 96.1 & 0.3 & - & - & - \\
\hline 2-Cyclopenten-1-one & Ps 8 & $\mathrm{C}_{5} \mathrm{H}_{6} \mathrm{O}$ & 82 & - & 3.3 & 2.5 & 1.3 \\
\hline 2-Cyclopenten-1-one, 2-methyl- & Ps9 & $\mathrm{C}_{6} \mathrm{H}_{8} \mathrm{O}$ & 96.1 & 3.1 & 3.1 & 1.3 & 0.5 \\
\hline 2-Furancarboxaldehyde & Ps 10 & $\mathrm{C}_{5} \mathrm{H}_{4} \mathrm{O}_{2}$ & 96 & - & - & - & 7.2 \\
\hline 2-Cyclopenten-1-one, 3-methyl- & Ps11 & $\mathrm{C}_{6} \mathrm{H}_{8} \mathrm{O}$ & 96.1 & 2.7 & 3 & 1.5 & - \\
\hline 2,3-Dimethyl-2-cyclopenten-1-one & Ps 12 & $\mathrm{C}_{7} \mathrm{H}_{10} \mathrm{O}$ & 110.1 & 2.1 & 1.2 & 0.4 & - \\
\hline 5 METHYL FURFURAL & Ps13 & $\mathrm{C}_{6} \mathrm{H}_{6} \mathrm{O}_{2}$ & 110 & 5.2 & 2.4 & 2.2 & 3.3 \\
\hline Benzofuran, 2-methyl- & Ps14 & $\mathrm{C}_{9} \mathrm{H}_{8} \mathrm{O}$ & 132.1 & 0.7 & 0.3 & 0.8 & 0.7 \\
\hline 3,5-DIMETHYL CYCLOPENTENOLONE & Ps 15 & $\mathrm{C}_{7} \mathrm{H}_{10} \mathrm{O}_{2}$ & 126.1 & - & 1.1 & - & - \\
\hline 2-Cyclopenten-1-one, 2-hydroxy-3-methyl- & Ps16 & $\mathrm{C}_{6} \mathrm{H}_{8} \mathrm{O}_{2}$ & 112.1 & - & 3.5 & - & - \\
\hline 2-Cyclopenten-1-one, 3-ethyl-2-hydroxy- & Ps17 & $\mathrm{C}_{7} \mathrm{H}_{10} \mathrm{O}_{2}$ & 126.1 & - & 0.4 & - & - \\
\hline Acetophenone & Lg1 & $\mathrm{C}_{8} \mathrm{H}_{8} \mathrm{O}$ & 120.1 & 1.1 & - & - & - \\
\hline Phenol, 2-methoxy- & Lg2 & $\mathrm{C}_{7} \mathrm{H}_{8} \mathrm{O}_{2}$ & 108.1 & - & 1.1 & 1.4 & - \\
\hline Phenol, 2-methyl- & Lg3 & $\mathrm{C}_{7} \mathrm{H}_{8} \mathrm{O}$ & 108.1 & 2 & 2.1 & 3.6 & 0.7 \\
\hline Phenol, 4-methyl- & Lg4 & $\mathrm{C}_{7} \mathrm{H}_{8} \mathrm{O}$ & 108.1 & - & 6.5 & 5 & 0.6 \\
\hline Phenol, 3-methyl- & $\operatorname{Lg} 5$ & $\mathrm{C}_{7} \mathrm{H}_{8} \mathrm{O}$ & 108.1 & 0.8 & - & 2.6 & 0.5 \\
\hline 1H-Pyrrole, 1-methyl- & N1 & $\mathrm{C}_{5} \mathrm{H}_{7} \mathrm{~N}$ & 81.1 & 1 & 0.9 & - & 1.9 \\
\hline Butanenitrile, 2-methylene- & N2 & $\mathrm{C}_{5} \mathrm{H}_{7} \mathrm{~N}$ & 81.1 & - & - & 0.1 & - \\
\hline Pyridine (CAS) & N3 & $\mathrm{C}_{5} \mathrm{H}_{5} \mathrm{~N}$ & 79 & - & 4.3 & - & - \\
\hline 2,4-Pentadienenitrile & N4 & $\mathrm{C}_{5} \mathrm{H}_{5} \mathrm{~N}$ & 79 & - & - & 7 & 24.7 \\
\hline Pyridine, 4-methyl- & N5 & $\mathrm{C}_{6} \mathrm{H}_{7} \mathrm{~N}$ & 93.1 & - & - & 2.5 & - \\
\hline Pyridine, 2-methyl- & N6 & $\mathrm{C}_{6} \mathrm{H}_{7} \mathrm{~N}$ & 93.1 & 3.6 & 3.4 & 3.4 & 5.6 \\
\hline Pyridine, 2,4-dimethyl- & N7 & $\mathrm{C}_{7} \mathrm{H}_{9} \mathrm{~N}$ & 107.1 & - & 0.4 & - & - \\
\hline Pyridine, 2,6-dimethyl- & N8 & $\mathrm{C}_{7} \mathrm{H}_{9} \mathrm{~N}$ & 107.1 & - & - & 0.6 & 0.5 \\
\hline Pyrazine, methyl- & N9 & $\mathrm{C}_{5} \mathrm{H}_{6} \mathrm{~N}_{2}$ & 94.1 & - & - & 0.8 & - \\
\hline 1H-Pyrrole-2-ethanamine, 1-methyl- & N10 & $\mathrm{C}_{7} \mathrm{H}_{12} \mathrm{~N}_{2}$ & 124.1 & 0.5 & - & - & 0.2 \\
\hline Pyridine, 2-ethyl- & N11 & $\mathrm{C}_{7} \mathrm{H}_{9} \mathrm{~N}$ & 107.1 & 0.5 & 0.5 & - & 0.4 \\
\hline Hexanenitrile & N12 & $\mathrm{C}_{6} \mathrm{H}_{11} \mathrm{~N}$ & 97.1 & 0.3 & - & - & - \\
\hline Pyridine, 3-methyl- & N13 & $\mathrm{C}_{6} \mathrm{H}_{7} \mathrm{~N}$ & 93.1 & - & 0.7 & - & - \\
\hline Pyridine, 3,5-dimethyl- & N14 & $\mathrm{C}_{7} \mathrm{H}_{9} \mathrm{~N}$ & 107.1 & - & - & 0.8 & 0.1 \\
\hline
\end{tabular}


Appendix

continued

\begin{tabular}{|c|c|c|c|c|c|c|c|}
\hline Pyridine, 2,4-dimethyl- & N15 & $\mathrm{C}_{7} \mathrm{H}_{9} \mathrm{~N}$ & 107.1 & - & 1.2 & 0.9 & 0.4 \\
\hline Pyridine, 2,3-dimethyl- & N16 & $\mathrm{C}_{7} \mathrm{H}_{9} \mathrm{~N}$ & 107.1 & - & 0.2 & - & 0.3 \\
\hline Pyridine, 3 -ethyl- & N17 & $\mathrm{C}_{7} \mathrm{H}_{9} \mathrm{~N}$ & 107.1 & 0.5 & - & 0.6 & 0.6 \\
\hline Pyridine, 4-ethyl- & N18 & $\mathrm{C}_{7} \mathrm{H}_{9} \mathrm{~N}$ & 107.1 & - & - & 0.1 & - \\
\hline Heptanenitrile & N19 & $\mathrm{C}_{7} \mathrm{H}_{13} \mathrm{~N}$ & 111.1 & - & - & 0.4 & - \\
\hline Pyridine, 3,4-dimethyl- & $\mathrm{N} 20$ & $\mathrm{C}_{7} \mathrm{H}_{9} \mathrm{~N}$ & 107.1 & 0.2 & - & - & - \\
\hline 1H-Pyrrole, 2-methyl- & $\mathrm{N} 21$ & $\mathrm{C}_{5} \mathrm{H}_{7} \mathrm{~N}$ & 81.1 & 3.2 & 4.1 & 1.2 & 0.6 \\
\hline 1H-Pyrrole, 2,5-dimethyl- & $\mathrm{N} 22$ & $\mathrm{C}_{6} \mathrm{H}_{9} \mathrm{~N}$ & 95.1 & 0.8 & 0.7 & - & - \\
\hline Pyridine, 3-methoxy- & $\mathrm{N} 23$ & $\mathrm{C}_{6} \mathrm{H}_{7} \mathrm{NO}$ & 109.1 & - & - & - & 0.5 \\
\hline Tricyclo $[3,1,0,02,6]$ hex-3-ene-3-carbonitrile & $\mathrm{N} 24$ & $\mathrm{C}_{7} \mathrm{H}_{5} \mathrm{~N}$ & 103 & - & - & - & 1.6 \\
\hline 1H-Pyrrole, 2-ethyl-4-methyl- & $\mathrm{N} 25$ & $\mathrm{C}_{7} \mathrm{H}_{11} \mathrm{~N}$ & 109.1 & 0.6 & 0.6 & - & - \\
\hline 1H-Pyrrole, $2,3,5$-trimethyl- & N26 & $\mathrm{C}_{7} \mathrm{H}_{11} \mathrm{~N}$ & 109.1 & 0.6 & - & 0.1 & - \\
\hline 1,2-Benzisoxazole & N27 & $\mathrm{C}_{7} \mathrm{H}_{5} \mathrm{NO}$ & 119 & - & - & - & 0.1 \\
\hline Benzonitrile, 2-methyl- & $\mathrm{N} 28$ & $\mathrm{C}_{8} \mathrm{H}_{7} \mathrm{~N}$ & 117.1 & 0.2 & - & - & - \\
\hline Benzonitrile, 3-methyl- & N29 & $\mathrm{C}_{8} \mathrm{H}_{7} \mathrm{~N}$ & 117.1 & - & - & 0.4 & - \\
\hline Benzonitrile, 4-methyl- & N30 & $\mathrm{C}_{8} \mathrm{H}_{7} \mathrm{~N}$ & 117.1 & - & 1 & 0.7 & 0.2 \\
\hline Benzoxazole, 2-methyl- & N31 & $\mathrm{C}_{8} \mathrm{H}_{7} \mathrm{NO}$ & 133.1 & - & 1.7 & 1.2 & 0.7 \\
\hline Benzenamine, 4-methoxy- & N32 & $\mathrm{C}_{7} \mathrm{H}_{9} \mathrm{NO}$ & 123.1 & 0.2 & - & - & - \\
\hline Benzene, 1-isocyano-4-methyl- & N33 & $\mathrm{C}_{8} \mathrm{H}_{7} \mathrm{~N}$ & 117.1 & 0.9 & - & 0.4 & 0.3 \\
\hline Benzonitrile, 4-hydroxy- & N34 & $\mathrm{C}_{7} \mathrm{H}_{5} \mathrm{NO}$ & 119 & - & - & - & 0.7 \\
\hline Aniline & N35 & $\mathrm{C}_{6} \mathrm{H}_{7} \mathrm{~N}$ & 93.1 & - & - & - & 0.5 \\
\hline Pyridine, 4-methyl- & N36 & $\mathrm{C}_{6} \mathrm{H}_{7} \mathrm{~N}$ & 93.1 & 0.4 & - & 0.6 & - \\
\hline 2,5-Dimethylbenzoxazole & N37 & $\mathrm{C}_{9} \mathrm{H}_{9} \mathrm{NO}$ & 147.1 & - & - & 0.1 & - \\
\hline 2,5-Dimethylbenzoxazole & N38 & $\mathrm{C}_{9} \mathrm{H}_{9} \mathrm{NO}$ & 147.1 & - & - & - & 0.1 \\
\hline Benzene, 1-isocyanato-3-methyl- & N39 & $\mathrm{C}_{8} \mathrm{H}_{7} \mathrm{NO}$ & 133.1 & - & - & - & 0.3 \\
\hline 1H-Indol-5-ol & $\mathrm{N} 40$ & $\mathrm{C}_{8} \mathrm{H}_{7} \mathrm{NO}$ & 133.1 & - & - & - & 0.2 \\
\hline 1H-Indole, 2-methyl- & $\mathrm{N} 41$ & $\mathrm{C}_{9} \mathrm{H}_{9} \mathrm{~N}$ & 131.1 & 0.2 & - & - & - \\
\hline 1H-Imidazole, 2-(4-methylphenyl)- & $\mathrm{N} 42$ & $\mathrm{C}_{10} \mathrm{H}_{10} \mathrm{~N}_{2}$ & 158.1 & 0.1 & - & - & - \\
\hline 2-Pyridinecarbonitrile & $\mathrm{N} 43$ & $\mathrm{C}_{6} \mathrm{H}_{4} \mathrm{~N}_{2}$ & 104 & - & 0.8 & - & - \\
\hline Benzylnitrile & N44 & $\mathrm{C}_{8} \mathrm{H}_{7} \mathrm{~N}$ & 117.1 & 0.7 & 1.6 & 1.9 & 0.7 \\
\hline Dodecanenitrile & N45 & $\mathrm{C}_{12} \mathrm{H}_{23} \mathrm{~N}$ & 181.2 & 0.2 & - & 0.1 & 0.2 \\
\hline Isoquinoline & $\mathrm{N} 46$ & $\mathrm{C}_{9} \mathrm{H}_{7} \mathrm{~N}$ & 129.1 & 0.3 & 0.5 & - & 0.3 \\
\hline Hexadecanenitrile & N47 & $\mathrm{C}_{16} \mathrm{H}_{31} \mathrm{~N}$ & 237.3 & - & - & 2.7 & - \\
\hline Undecanenitrile & N48 & $\mathrm{C}_{11} \mathrm{H}_{21} \mathrm{~N}$ & 167.2 & 0.1 & - & - & - \\
\hline Benzenepropanenitrile & N49 & $\mathrm{C}_{9} \mathrm{H}_{9} \mathrm{~N}$ & 131.1 & - & 2.1 & - & - \\
\hline 7-Propylfuro[3,2-b]pyridine & N50 & $\mathrm{C}_{10} \mathrm{H}_{11} \mathrm{NO}$ & 161.1 & - & - & - & 0.1 \\
\hline Cyclopropane, ethylidene- & I1 & $\mathrm{C} 5 \mathrm{H} 8$ & 68.1 & - & - & 3.5 & - \\
\hline 1,3-Butadiene, 2-methyl- & I2 & $\mathrm{C} 5 \mathrm{H} 8$ & 68.1 & 0.4 & 0.7 & - & 0.8 \\
\hline 1,4-Cyclohexadiene, 1-methyl- & I3 & C7H10 & 94.1 & 0.7 & - & - & - \\
\hline 1,3,5-Hexatriene, 3-methyl-, (Z)- & I4 & $\mathrm{C} 7 \mathrm{H} 10$ & 94.1 & 1.1 & 0.4 & - & 0.2 \\
\hline 1,4-Cyclohexadiene, 1 -methyl- & I5 & $\mathrm{C} 7 \mathrm{H} 10$ & 94.1 & 0.3 & - & - & - \\
\hline 2-METHYL-CYCLOHEXA-1,3-DIENE & I6 & $\mathrm{C} 7 \mathrm{H} 10$ & 94.1 & 0.1 & - & - & - \\
\hline OCTA-2,4,6-TRIENE & I7 & $\mathrm{C} 8 \mathrm{H} 12$ & 108.1 & 0.5 & - & - & - \\
\hline 1,3-Cyclopentadiene, trimethyl- & I8 & $\mathrm{C} 8 \mathrm{H} 12$ & 108.1 & - & 0.4 & - & - \\
\hline 1-Nonene & Lp1 & $\mathrm{C} 9 \mathrm{H} 18$ & 126.1 & - & 0.8 & - & - \\
\hline 1-Decene & Lp2 & $\mathrm{C} 10 \mathrm{H} 20$ & 140.2 & 0.7 & 0.7 & - & 0.4 \\
\hline 4-Decene & Lp3 & $\mathrm{C} 10 \mathrm{H} 20$ & 140.2 & 0.8 & 0.1 & 0.1 & 0.3 \\
\hline cis-3-Decene & Lp4 & $\mathrm{C} 10 \mathrm{H} 20$ & 140.2 & - & - & - & 0.4 \\
\hline Undecane & Lp5 & $\mathrm{C} 11 \mathrm{H} 24$ & 156.2 & 1.1 & 0.7 & 0.7 & 0.4 \\
\hline
\end{tabular}


continued

\begin{tabular}{|c|c|c|c|c|c|c|c|}
\hline 4-Undecene, (E)- & Lp6 & $\mathrm{C}_{11} \mathrm{H}_{22}$ & 154.2 & - & - & - & 0.5 \\
\hline 5-Undecene, (E)- & Lp7 & $\mathrm{C}_{11} \mathrm{H}_{22}$ & 154.2 & 0.5 & - & 0.1 & 0.6 \\
\hline 1-Undecene & Lp8 & $\mathrm{C}_{11} \mathrm{H}_{22}$ & 154.2 & 0.8 & 1 & - & 0.7 \\
\hline Cyclopropane, 1,2-dibutyl- & Lp9 & $\mathrm{C}_{11} \mathrm{H}_{22}$ & 154.2 & - & - & 0.1 & 0.2 \\
\hline Dodecane & Lp10 & $\mathrm{C}_{12} \mathrm{H}_{26}$ & 170.2 & 0.4 & 0.5 & - & 0.2 \\
\hline Eicosane & Lp11 & $\mathrm{C}_{20} \mathrm{H}_{42}$ & 282.3 & - & - & 0.4 & - \\
\hline 1-Dodecene & Lp12 & $\mathrm{C}_{12} \mathrm{H}_{24}$ & 168.2 & 0.8 & 1 & - & - \\
\hline Cyclododecane & Lp13 & $\mathrm{C}_{12} \mathrm{H}_{24}$ & 168.2 & - & - & 0.1 & - \\
\hline Tridecane & Lp14 & $\mathrm{C}_{13} \mathrm{H}_{28}$ & 184.2 & 0.8 & 0.6 & 0.2 & - \\
\hline 6-Tridecene, (Z)- & Lp15 & $\mathrm{C}_{13} \mathrm{H}_{26}$ & 182.2 & - & - & - & 0.4 \\
\hline 1-Tridecene & Lp16 & $\mathrm{C}_{13} \mathrm{H}_{26}$ & 182.2 & 0.9 & 0.7 & - & - \\
\hline Tetradecane & Lp17 & $\mathrm{C}_{14} \mathrm{H}_{30}$ & 198.2 & 0.8 & - & 0.2 & - \\
\hline 1-Tetradecene & Lp18 & $\mathrm{C}_{14} \mathrm{H}_{28}$ & 196.2 & 0.6 & 0.5 & - & - \\
\hline 2-Tetradecene, (E)- & Lp19 & $\mathrm{C}_{14} \mathrm{H}_{28}$ & 196.2 & - & - & - & 0.3 \\
\hline 7-Hexadecene, (Z)- & Lp20 & $\mathrm{C}_{16} \mathrm{H}_{32}$ & 224.3 & - & - & - & 0.3 \\
\hline 1-Pentadecene & Lp21 & $\mathrm{C}_{15} \mathrm{H}_{30}$ & 210.2 & 0.4 & - & 0.4 & 0.9 \\
\hline pentadecane & Lp22 & $\mathrm{C}_{15} \mathrm{H}_{32}$ & 212.3 & 0.6 & 0.8 & 0.7 & - \\
\hline Methyl 7,9-tridecadienyl ether & Lp23 & $\mathrm{C}_{14} \mathrm{H}_{26} \mathrm{O}$ & 210.2 & - & - & - & 0.2 \\
\hline 2,4-Hexadiene, 2,5-dimethyl- & Lp24 & $\mathrm{C}_{8} \mathrm{H}_{14}$ & 110.1 & 0.5 & - & - & - \\
\hline 8-Heptadecene & Lp25 & $\mathrm{C}_{17} \mathrm{H}_{34}$ & 238.3 & - & - & - & 0.1 \\
\hline 1-Hexadecene & Lp26 & $\mathrm{C}_{16} \mathrm{H}_{32}$ & 224.3 & 0.7 & - & 0.2 & 0.4 \\
\hline Heptadecane & Lp27 & $\mathrm{C}_{17} \mathrm{H}_{36}$ & 240.3 & 0.8 & - & - & 0.5 \\
\hline Octadecane & Lp28 & $\mathrm{C}_{18} \mathrm{H}_{38}$ & 254.3 & 0.3 & - & - & 0.3 \\
\hline 1-Octadecene & Lp29 & $\mathrm{C}_{18} \mathrm{H}_{36}$ & 252.3 & 0.6 & 0.6 & 0.7 & - \\
\hline Nonadecane & Lp30 & $\mathrm{C}_{19} \mathrm{H}_{40}$ & 268.3 & - & - & 2.2 & - \\
\hline 1-Nonadecene & Lp31 & $\mathrm{C}_{19} \mathrm{H}_{38}$ & 266.3 & - & - & 1.7 & - \\
\hline 9-Nonadecene & Lp32 & $\mathrm{C}_{19} \mathrm{H}_{38}$ & 266.3 & - & - & 0.1 & - \\
\hline Z-5-Nonadecene & Lp33 & $\mathrm{C}_{19} \mathrm{H}_{38}$ & 266.3 & - & - & 0.2 & - \\
\hline 5-Eicosene, (E)- & Lp34 & $\mathrm{C}_{20} \mathrm{H}_{40}$ & 280.3 & - & - & 0.5 & - \\
\hline Heneicosane & Lp35 & $\mathrm{C}_{21} \mathrm{H}_{44}$ & 296.3 & - & - & 0.2 & - \\
\hline Butanal, 3-methyl- & Ar1 & $\mathrm{C}_{5} \mathrm{H}_{10} \mathrm{O}$ & 86.1 & 0.4 & - & - & - \\
\hline Benzene & $\mathrm{Ar} 2$ & $\mathrm{C}_{6} \mathrm{H}_{6}$ & 78.1 & 3.3 & - & 3.2 & 2.8 \\
\hline Benzene, methyl- & Ar3 & $\mathrm{C}_{7} \mathrm{H}_{8}$ & 92.1 & 8.6 & 11 & 8.8 & 5.3 \\
\hline Benzene, ethyl- & Ar4 & $\mathrm{C}_{8} \mathrm{H}_{10}$ & 106.1 & 2.2 & 1.5 & 1.4 & 1.4 \\
\hline Benzene, 1,3-dimethyl- & Ar5 & $\mathrm{C}_{8} \mathrm{H}_{10}$ & 106.1 & 1.3 & - & 0.7 & 1 \\
\hline Benzene, 1,2-dimethyl- & Ar6 & $\mathrm{C}_{8} \mathrm{H}_{10}$ & 106.1 & - & 0.9 & 1.3 & - \\
\hline p-Xylene & Ar7 & $\mathrm{C}_{8} \mathrm{H}_{10}$ & 106.1 & 1.7 & 1 & - & 1.3 \\
\hline Phenol, 3-methyl- & Ar8 & $\mathrm{C}_{7} \mathrm{H}_{8} \mathrm{O}$ & 108.1 & - & 0.2 & - & - \\
\hline Benzene, 1,2-dimethyl- & Ar9 & $\mathrm{C}_{8} \mathrm{H}_{10}$ & 106.1 & 1.5 & - & - & 0.9 \\
\hline Benzene, 1,3-dimethyl- & Ar10 & $\mathrm{C}_{8} \mathrm{H}_{10}$ & 106.1 & - & 0.8 & 1.1 & - \\
\hline Benzene, 1-ethyl-2-methyl- & Ar11 & $\mathrm{C}_{9} \mathrm{H}_{12}$ & 120.1 & 0.7 & - & - & - \\
\hline Benzene, 1-ethyl-3-methyl- & Ar12 & $\mathrm{C}_{9} \mathrm{H}_{12}$ & 120.1 & - & - & 0.4 & 0.5 \\
\hline Benzene, 1,3,5-trimethyl- & Ar13 & $\mathrm{C}_{9} \mathrm{H}_{12}$ & 120.1 & 0.1 & - & - & - \\
\hline Styrene \$ \$ Benzene, ethenyl- & Ar14 & $\mathrm{C}_{8} \mathrm{H}_{8}$ & 104.1 & 1.8 & 2.3 & 1.5 & 1.5 \\
\hline Benzene, 1-ethyl-2-methyl- & Ar15 & $\mathrm{C}_{9} \mathrm{H}_{12}$ & 120.1 & - & 0.3 & - & - \\
\hline Benzene, 1-ethyl-4-methyl- & Ar16 & $\mathrm{C}_{9} \mathrm{H}_{12}$ & 120.1 & - & - & 0.4 & - \\
\hline Benzene, 2-propenyl- & Ar17 & $\mathrm{C}_{9} \mathrm{H}_{10}$ & 118.1 & - & 0.2 & - & - \\
\hline Benzene, 1,2,4-trimethyl- & Ar18 & $\mathrm{C}_{9} \mathrm{H}_{12}$ & 120.1 & 0.7 & 0.5 & - & 0.8 \\
\hline Benzene, 1-methyl-3-propyl- & Ar19 & $\mathrm{C}_{10} \mathrm{H}_{14}$ & 134.1 & 0.2 & - & - & - \\
\hline Benzene, (1-methylpropyl)- & Ar20 & $\mathrm{C}_{10} \mathrm{H}_{14}$ & 134.1 & 0.2 & - & - & 0.3 \\
\hline
\end{tabular}


Appendix

continued

\begin{tabular}{|c|c|c|c|c|c|c|c|}
\hline Benzene, 1-propenyl- & $\mathrm{Ar} 21$ & $\mathrm{C}_{9} \mathrm{H}_{10}$ & 118.1 & - & - & 0.1 & - \\
\hline Benzene, 2-propenyl- & Ar22 & $\mathrm{C}_{9} \mathrm{H}_{10}$ & 118.1 & - & 0.5 & 0.2 & 0.2 \\
\hline Benzene, cyclopropyl- & Ar23 & $\mathrm{C}_{9} \mathrm{H}_{10}$ & 118.1 & 0.3 & - & - & - \\
\hline ,alpha,-Methylstyrene & Ar24 & $\mathrm{C}_{9} \mathrm{H}_{10}$ & 118.1 & - & - & - & 0.3 \\
\hline Benzene, 1-ethyl-3-methyl- & $\operatorname{Ar} 25$ & $\mathrm{C}_{9} \mathrm{H}_{12}$ & 120.1 & - & - & 0.3 & 0.4 \\
\hline Benzene, 1-ethyl-2,3-dimethyl- & Ar26 & $\mathrm{C}_{10} \mathrm{H}_{14}$ & 134.1 & - & - & 0.1 & - \\
\hline Benzene, 1-ethenyl-3-methyl- & $\operatorname{Ar} 27$ & $\mathrm{C}_{9} \mathrm{H}_{10}$ & 118.1 & - & - & - & 0.3 \\
\hline Benzene, 4-ethyl-1,2-dimethyl- & Ar28 & $\mathrm{C}_{10} \mathrm{H}_{14}$ & 134.1 & - & - & - & 0.1 \\
\hline Benzene, 1-ethenyl-3-methyl- & Ar29 & $\mathrm{C}_{9} \mathrm{H}_{10}$ & 118.1 & - & - & 0.3 & - \\
\hline 1-METHYL-2-PHENYLCYCLOPROPANE 2 & Ar30 & $\mathrm{C}_{10} \mathrm{H}_{12}$ & 132.1 & 0.4 & - & - & - \\
\hline Benzene, 2-butenyl- & Ar31 & $\mathrm{C}_{10} \mathrm{H}_{12}$ & 132.1 & 0.2 & - & - & - \\
\hline 2,4-Dimethylstyrene & Ar32 & $\mathrm{C}_{10} \mathrm{H}_{12}$ & 132.1 & - & - & - & 0.1 \\
\hline Benzene, 1-methyl-4-(2-methylpropyl)- & Ar33 & $\mathrm{C}_{11} \mathrm{H}_{16}$ & 148.1 & - & - & - & 0.7 \\
\hline Benzene, 1-propynyl- & Ar34 & $\mathrm{C}_{9} \mathrm{H}_{8}$ & 116.1 & - & - & 1 & 0.4 \\
\hline 1-METHYL-2-PHENYLCYCLOPROPANE 1 & $\operatorname{Ar} 35$ & $\mathrm{C}_{10} \mathrm{H}_{12}$ & 132.1 & 0.8 & - & - & - \\
\hline Benzene, 1,4-dimethyl-2-(2-methylpropyl)- & Ar36 & $\mathrm{C}_{12} \mathrm{H}_{18}$ & 162.1 & - & - & - & 0.4 \\
\hline Benzene, hexyl- & $\operatorname{Ar} 37$ & $\mathrm{C}_{12} \mathrm{H}_{18}$ & 162.1 & 0.2 & - & - & 0.3 \\
\hline Benzaldehyde & $\operatorname{Ar} 38$ & $\mathrm{C}_{7} \mathrm{H}_{6} \mathrm{O}$ & 108.1 & - & - & - & 0.8 \\
\hline Benzene, 1-butynyl- & Ar39 & $\mathrm{C}_{10} \mathrm{H}_{10}$ & 130.1 & - & - & - & 0.2 \\
\hline Benzene, heptyl- & Ar40 & $\mathrm{C}_{13} \mathrm{H}_{20}$ & 176.2 & - & - & - & 0.1 \\
\hline Benzene, 1,3-butadienyl- & Ar41 & $\mathrm{C}_{10} \mathrm{H}_{10}$ & 130.1 & - & - & 0.6 & - \\
\hline Benzaldehyde, 2-methyl- & $\operatorname{Ar} 42$ & $\mathrm{C}_{8} \mathrm{H}_{8} \mathrm{O}$ & 120.1 & - & - & - & 0.1 \\
\hline Benzaldehyde, 2-hydroxy- & Ar43 & $\mathrm{C}_{7} \mathrm{H}_{6} \mathrm{O}_{2}$ & 122 & - & - & - & 0.1 \\
\hline Benzene, (1-methyl-1-butenyl)- & Ar44 & $\mathrm{C}_{11} \mathrm{H}_{14}$ & 146.1 & 0.2 & - & - & - \\
\hline (1-Methylbuta-1,3-dienyl)benzene & Ar45 & $\mathrm{C}_{11} \mathrm{H}_{12}$ & 144.1 & 0.4 & - & - & - \\
\hline Phenol, 2,6-dimethyl- & Ar46 & $\mathrm{C}_{8} \mathrm{H}_{10} \mathrm{O}$ & 122.1 & 0.4 & 0.7 & 0.4 & - \\
\hline Phenol & Ar47 & $\mathrm{C}_{6} \mathrm{H}_{6} \mathrm{O}$ & 94 & 3.3 & 6.1 & 9.9 & 2.7 \\
\hline Phenol, 2-ethyl- & Ar48 & $\mathrm{C}_{8} \mathrm{H}_{10} \mathrm{O}$ & 122.1 & 0.3 & - & - & - \\
\hline Benzene, (1-hexylheptyl)- & Ar49 & $\mathrm{C}_{19} \mathrm{H}_{32}$ & 260.3 & - & - & - & 0.4 \\
\hline Phenol, 4-methyl- & Ar50 & $\mathrm{C}_{7} \mathrm{H}_{8} \mathrm{O}$ & 108.1 & 1.8 & 1.9 & - & - \\
\hline Phenol, 2,6-dimethyl- & Ar51 & $\mathrm{C}_{8} \mathrm{H}_{10} \mathrm{O}$ & 122.1 & 0.4 & - & - & - \\
\hline Phenol, 3-ethyl- & Ar52 & $\mathrm{C}_{8} \mathrm{H}_{10} \mathrm{O}$ & 122.1 & 0.7 & - & - & - \\
\hline Benzene, (1-methyldodecyl)- & Ar53 & $\mathrm{C}_{19} \mathrm{H}_{32}$ & 260.3 & - & - & - & 1.6 \\
\hline Indene & $\mathrm{BC} 1$ & $\mathrm{C}_{9} \mathrm{H}_{8}$ & 116.1 & 1.4 & 1.6 & - & 0.2 \\
\hline 1H-Indene, 1-methyl- & $\mathrm{BC} 2$ & $\mathrm{C}_{10} \mathrm{H}_{10}$ & 130.1 & 6.1 & 1.3 & 0.4 & 0.3 \\
\hline Naphthalene, 1,2-dihydro- & $\mathrm{BC} 3$ & $\mathrm{C}_{10} \mathrm{H}_{10}$ & 130.1 & - & - & 0.4 & - \\
\hline 1H-Indene, 1,1-dimethyl- & $\mathrm{BC} 4$ & $\mathrm{C}_{11} \mathrm{H}_{12}$ & 144.1 & 1.2 & - & 0.3 & - \\
\hline $\begin{array}{l}1 \mathrm{H}-\text { Cyclopropa[b]naphthalene, 1a,2,7,7a- } \\
\text { tetrahydro- }\end{array}$ & BC5 & $\mathrm{C}_{11} \mathrm{H}_{12}$ & 144.1 & 0.5 & - & - & - \\
\hline 1H-Indene, 4,7-dimethyl- & $\mathrm{BC} 6$ & $\mathrm{C}_{11} \mathrm{H}_{12}$ & 144.1 & 0.4 & - & - & - \\
\hline Naphthalene & $\mathrm{BC} 7$ & $\mathrm{C}_{10} \mathrm{H}_{8}$ & 128.1 & 1.3 & 1.2 & 0.8 & 0.6 \\
\hline Naphthalene, 1-methyl- & $\mathrm{BC} 8$ & $\mathrm{C}_{11} \mathrm{H}_{10}$ & 142.1 & 1.1 & 0.8 & 2 & 0.3 \\
\hline 1H-Inden-1-one, 2,3-dihydro-3-methyl- & ВC9 & $\mathrm{C}_{10} \mathrm{H}_{10} \mathrm{O}$ & 146.1 & - & 0.6 & - & - \\
\hline Naphthalene, 1,3-dimethyl- & $\mathrm{BC} 10$ & $\mathrm{C}_{12} \mathrm{H}_{12}$ & 156.1 & - & - & 0.3 & - \\
\hline 1,1'-Biphenyl & $\mathrm{BC} 11$ & $\mathrm{C}_{12} \mathrm{H}_{10}$ & 154.1 & 0.5 & 0.9 & - & 4.8 \\
\hline Naphthalene, 2,7-dimethyl- & $\mathrm{BC} 12$ & $\mathrm{C}_{12} \mathrm{H}_{12}$ & 156.1 & - & - & - & 0.2 \\
\hline Naphthalene, 2,6-dimethyl- & $\mathrm{BC} 13$ & $\mathrm{C}_{12} \mathrm{H}_{12}$ & 156.1 & 0.4 & - & - & - \\
\hline 1H-Inden-1-one, 2,3-dihydro- & $\mathrm{BC} 14$ & $\mathrm{C}_{9} \mathrm{H}_{8} \mathrm{O}$ & 132.1 & 0.9 & 1.3 & - & - \\
\hline Fluorene & $\mathrm{BC} 15$ & $\mathrm{C}_{13} \mathrm{H}_{10}$ & 166.1 & 0.5 & 0.3 & - & - \\
\hline
\end{tabular}

